\title{
Mary Wollstonecraft's Political Political Theory
}

\author{
Elizabeth Frazer
}

\begin{abstract}
This paper separates Wollstonecraft's critical concept of "machiavelian" power and the capacity for domination, from a neutral concept of politics as the complex processes surrounding the power to govern, from her normative account of popular sovereignty which emphasizes collective political power to ensure the discharge of natural duty by way of civil and political rights and duties. Wollstonecraft's voice as political judge-which is audible throughout her work, but particularly clearly in her book on the French Revolution-articulates the ways that political power can be abused and misused, and can also be effective. Her theory is political in several ways: she interrogates the nature of political power and its explanatory importance; she consistently articulates political judgment about matters both conventionally political and social; she offers a theoretical justification for the expansion of the scope of politics to cover relations that hitherto were thought to be outside its domain; and finally her work itself constitutes a political intervention.
\end{abstract}

\section{Introduction}

This paper analyzes the political nature of Mary Wollstonecraft's political theory. It takes at its word the title of A Vindication of the Rights of Woman, with Strictures on Political and Moral Subjects. ${ }^{1}$ Wollstonecraft's analyses of manners and morals, socialization and education, and the economic and political effects of cultural norms of course problematize the categories of politics and the political. In the Analytic Review "catalogue of books and pamphlets published in the first six months of 1792" the Vindication appears,

Elizabeth Frazer is Associate Professor of Politics in the Department of Politics and International Relations at University of Oxford, Manor Road Building, Manor Road, Oxford, OX1 3UQ, United Kingdom (Elizabeth.frazer@new.ox.ac.uk).

I am very grateful to Alan Coffee and Kim Hutchings for comments on earlier drafts of this paper, to participants in the Wollstonecraft workshop, APSA September 2017, who inspired this work, and to the editor and anonymous reviewers for detailed and helpful criticisms and suggestions.

${ }^{1}$ Mary Wollstonecraft, A Vindication of the Rights of Woman, in Mary Wollstonecraft: Political Writings, ed. Janet Todd (Oxford: Oxford University Press, 1994). 
not, to be sure, under the heading "politics" - where Thomas Paine's Rights of Man and other volumes responding to Paine and to Edmund Burke's Reflections on the Revolution in France are listed-but under "political oeconomy." ${ }^{2}$ This classification is suggestive of the controversies and difficulties, which commentators on Wollstonecraft's work have discussed, both with the inclusion of a woman author's book on rights in the political culture of late eighteenth century Britain, and, even more, with the inclusion of a woman author's book on women's rights in the category of politics. ${ }^{3}$ Wollstonecraft challenges the confinement of politics to the sphere of statecraft, and the exclusion of intimate and domestic relationships from the field of political concern. ${ }^{4}$

This aspect of her analysis has been understood as seminally significant both by those who are critical of her moralistic censure of women's conduct and of sexual passion, and by those for whom her analysis of the stabilization and enforcement of ideologies of femininity and sexual difference set a standard for later feminist critique and action. ${ }^{5}$ Wollstonecraft's theory of duties and rights, of government and sovereignty, indissolubly connects intimate, social, cultural, economic, and political relationships and institutions, and refuses to classify these sexually. Political life is not, properly, for men only. What follows, for critical and feminist theory, continues to be contentious. The idea that personal matters and social relationships are political too is widely endorsed, although as Mary Dietz points out, what follows for normative and practical approaches to political action as such, and in particular to the conventionally political field of state authority and administration, and the competition for governing power, is contested. ${ }^{6}$ Wollstonecraft's own emphasis on morality, and the power of her critique of cultural norms,

2“A Catalogue of Books and Pamphlets Published in the First Six Months of 1792," The Analytical Review 13, no. 4 (1792): 534-36; Catherine Packham, "Domesticity, Objects and Idleness: Mary Wollstonecraft and Political Economy," Women's Writing 19, no. 4 (2012): 545-46.

${ }^{3}$ Wendy Gunther-Canada, Rebel Writer: Mary Wollstonecraft and Enlightenment Politics (De Kalb: Northern Illinois University Press, 2001), 6; Packham, “Domesticity, Objects and Idleness," 546.

${ }^{4}$ Ruth Abbey, "Are Women Human? Wollstonecraft's Defense of Rights for Women," in A Vindication of the Rights of Woman, by Mary Wollestonecraft, ed. Eileen Hunt Botting (New Haven, CT: Yale University Press, 2014), 239; Eileen Hunt Botting, "The Personal Is Political: Wollstonecraft's Witty First Person Feminist Voice," in Botting, ed., A Vindication of the Rights of Woman, 261-79.

${ }^{5}$ Cora Kaplan, "Wild Nights: Pleasure/Sexuality/Feminism," in Sea Changes: Essays on Culture and Feminism (London: Verso, 1986); "Mary Wollstonecraft's Reception and Legacies," in The Cambridge Companion to Mary Wollstonecraft, ed. Claudia L. Johnson (Cambridge: Cambridge University Press, 2002).

${ }^{6}$ Mary G Dietz. "Context Is All: Feminism and Theories of Citizenship," in Dimensions of Radical Democracy, ed. Chantal Mouffe (London: Verso, 1992); Botting, "The Personal Is Political." 
could be interpreted as supporting the view that transforming morality and culture is more significant than conventional formally political actions like voting or standing for office or campaigning for state legislation. ${ }^{7}$ She can also be understood in the frame of the mainly liberal twentieth-century view that political theory is no more than the application of moral notions in the sphere of political relations. ${ }^{8}$

Against both of these interpretations, this paper emphasizes her explicit thematizations of "political power" and her view, consistent throughout her published works, that "machiavelianism" ${ }^{9}$ must be displaced by popular sovereignty, as well as her expanded conception of citizenship that includes presence and action in households, in work, and in public social settings, as much as in relation to state government. It also examines the political nature of her authorial voice. The Vindication of the Rights of Men is a direct contribution to an immediate, public debate about how the business of states should be managed, how government conduct should be constrained, and how justice should be realized in state and society. ${ }^{10}$ The Vindication of the Rights of Woman is addressed to a prominent statesman, and includes a persuasive plea to him to secure women's rights, in the tradition of earnest "advice to princes." 11 Her book on the French Revolution, with its avowed "historical and moral" perspective, is as much replete with political as with moral judgment. The same applies to Residence in Sweden. ${ }^{12}$ That is, Wollstonecraft's voice is that of a political actor, and her political theory

${ }^{7}$ Interpretations such as that Wollstonecraft's Rights of Woman is not really about politics, or much about rights, can be understood in this frame: see Ruth Abbey, "Are Women Human?," 229-30 for an account of this view; Virginia Sapiro, A Vindication of Political Virtue: The Political Theory of Mary Wollstonecraft (Chicago: University of Chicago Press, 1992), xx, xxv, 118-20, for partial endorsement.

${ }^{8}$ For instance, Isaiah Berlin, "Two Concepts of Liberty," in Four Essays on Liberty (Oxford: Oxford University Press, 1969), 120.

${ }^{9}$ Wollstonecraft cites "Machiavel's prince," or, rather, "the insidious tenets he gave to his prince": Wollstonecraft, An Historical and Moral View of the Origin and Progress of the French Revolution and the Effect It Has Produced in Europe, ed. Janet Todd (Delmar, NY: Scholars' Facsimiles and Reprints, 1975), 236. Throughout I follow her spelling of "machiavelian" with one $l$ rather than the two of twenty-first-century usage; except in direct quotation, I impose a lowercase $m$ in order to distance her construction from the real Niccolò Machiavelli's complex account of republican power. For the construction of "the Machiavel" in Elizabethan and later English political culture, see Sydney Anglo, Machiavelli-the First Century: Studies in Enthusiasm, Hostility and Irrelevance (Oxford: Oxford University Press, 2005).

${ }^{10}$ Mary Wollstonecraft, A Vindication of the Rights of Men, in Todd, ed., Political Writings

${ }^{11}$ Rights of Woman, Dedication “To M. Talleyrand Perigord," 65-70.

${ }^{12}$ Mary Wollstonecraft and William Godwin, A Short Residence in Sweden, Norway and Denmark and Memoirs, ed. Richard Holmes (Harmondsworth: Penguin Books, 1987). 
constitutes political intervention. This political intervention is one moment in more pervasive attention, throughout her work, on the question how political, as well as moral and cultural, transformation can be realized. Her focus on political power shows that for her politics is not reducible-to culture, morality, or anything else.

Scholars and critics have focused relatively little on this theme of what Wollstonecraft has to say about politics and the concept of politics, and how she speaks politically, and much more on the way what she says about politics is infused with other philosophical preoccupations. Her political theory, including her implicit and explicit critical views-of Lockean natural rights and education, of Rousseau's account of education and freedom, of Scottish enlightenment accounts of commercial society and individual rights, of Burke's account of political authority, of the American and French assertions of universal rights - can be understood through the frame of her critique of aesthetics and culture. ${ }^{13}$ How women are represented, in art, culture, and philosophy - and in particular the associations of femininity with beauty, with weakness, with chaos-clearly have implications for how women are represented and treated in politics, government, and laws. Wollstonecraft's work specifically clarifies these themes and puts them squarely on the agendas of feminist and political theory. Similarly, her critical political strictures, and her normative political project, have to be understood in the context of her (changing) theological understandings and her religious commitments. ${ }^{14}$ Her plea to Talleyrand and her prescription of political and legal rights for women and working class people, her analysis of the French

${ }^{13}$ Saba Bahar, Mary Wollstonecraft's Social and Aesthetic Philosophy: "An Eve to Please $M e^{\prime \prime}$ (Basingstoke: Palgrave, 2002); Gunther-Canada; "The Politics of Sense and Sensibility: Mary Wollstonecraft and Catharine Macaulay Graham on Edmund Burke's Reflections on the Revolution in France," in Women Writers and the Early Modern British Political Tradition, ed. Hilda L. Smith (Cambridge: Cambridge University Press, 1998); Gunther-Canada, Rebel Writer; Catherine Packham, “Genre and the Mediation of Political Economy in Edmund Burke's Reflections on the Revolution in France and Mary Wollstonecraft's A Vindication of the Rights of Men," Eighteenth Century: Theory and Interpretation (forthcoming).

${ }^{14}$ Barbara Taylor, "The Religious Foundations of Mary Wollstonecraft's Feminism," in Johnson, ed., Cambridge Companion to Mary Wollstonecraft; Taylor, Mary Wollstonecraft and the Feminist Imagination (Cambridge: Cambridge University Press, 2003) for the significance of her theistic framework for her conception of political progress and her perfectionist ethics; Eileen Hunt Botting, Family Feuds: Wollstonecraft, Burke, and Rousseau on the Transformation of the Family (NY: State University of New York Press, 2006), 134-36 on the interaction between Wollstonecraft's evolving theology and her political account of family relations; Botting, Wollstonecraft, Mill, and Women's Human Rights (New Haven, CT: Yale University Press, 2016), 51-66 on how her rational theology conditions her understanding of rights; Eileen Hunt Botting and Ariana Zlioba, "Religion and Women's Rights: Susan Moller Okin, Mary Wollstonecraft, and the Multiple Feminist Liberal Traditions," History of 
revolution, and her critique of social institutions, economy and government in Scandinavia all, further, are notable for her materialist or political economic analysis which can be read in the frame of developing science and political science. $^{15}$

Similarly, analysis of Wollstonecraft's focus on the production and distribution of material goods-housing, income, wealth, welfare, health - has frequently been framed by controversies within political and feminist theory since the 1970s about how she fits into identifiable traditions of political thought and action. As commentators have discussed, she has oftenbecause of the theme of rights, and the congeniality of her arguments to later campaigns for the inclusion of women in public institutions-been assimilated into the later liberal tradition. ${ }^{16}$ She has also been positioned in relation to later socialist and radical political thought and theory. ${ }^{17}$ Historians have insisted on her English Jacobin identity, and the relevance of commonwealth or country Whig arguments for our understanding of her political thought. ${ }^{18}$ The recent neorepublican challenge to liberal and socialist frames alike in political theory and philosophy has turned to feminist themes of the oppressive nature of dominating power whether exercised or not, and to the importance of action in concert in public in order that people dominate government rather than the other way round, to find marked affinities between feminism and republicanism. ${ }^{19}$ These controversies

European Ideas 44, no. 8(2018): 1169-88 on how her religious commitment makes her an ambiguous figure for twentieth-century political theorists.

${ }^{15}$ Catherine Packham, "The Common Grievance of the Revolution: Bread, the Grain Trade, and Political Economy in Wollstonecraft's View of the French Revolution," European Romantic Review 25, no. 6 (2014): 705-22; Packham, "Mary Wollstonecraft's Cottage Economics: Property, Political Economy, and the European Future," ELH 84, no. 2 (2017): 453-74.

${ }^{16}$ Sapiro, Vindication of Political Virtue, xx; Eileen Hunt Botting and Christine Carey, "Wollstonecraft's Philosophical Impact on Nineteenth-Century American Women's Rights Advocates," American Journal of Political Science 48, no. 4 (2004): 707-22; Eileen Hunt Botting, Christine Carey Wilkerson, and Elizabeth N. Kozlow, "Wollstonecraft as an International Feminist Meme," Journal of Women's History 26, no. 2 (2014): 16-18.

${ }^{17}$ Barbara Taylor, Eve and the New Jerusalem: Socialism and Feminism in the Nineteenth Century (London: Virago, 1983), 5-6.

${ }^{18}$ Taylor, Wollstonecraft and Feminist Imagination, 10-11.

${ }^{19}$ Lena Halldenius, Mary Wollstonecraft and Feminist Republicanism: Independence, Rights and the Experience of Unfreedom (London: Pickering and Chatto, 2015); Alan Coffee, "Mary Wollstonecraft, Freedom, and the Enduring Power of Social Domination," European Journal of Political Theory 12, no. 2 (2012); Coffee, "Freedom as Independence: Mary Wollstonecraft and the Grand Blessing of Life," Hypatia 29, no. 4 (2014): 908-24; Coffee, "Mary Wollstonecraft, Public Reason and the Virtuous Republic," in The Social and Political Philosophy of Mary Wollstonecraft, ed. Sandrine 
about how to characterize Wollstonecraft's relationship to political traditions, and to intellectual traditions such as civic humanism and enlightenment, generate diverse analyses of Wollstonecraft's conceptions of freedom, equality, rights, authority, gender, and other key concepts. ${ }^{20}$

In the next section I analyze Wollstonecraft's conception, and her use, of the concept of politics, separating out her "strictures" about self-interested domination by those who govern, and about "machiavelian" duplicity and cunning, from her account of the reality and the normativity of popular sovereignty and the possibility of just government. In section 3 I elaborate Wollstonecraft's normative political theory further, analyzing how her ethical and metaphysical commitments to simplicity and to progress, and her conceptions of duty and right, connect with her analysis of justice in political economy. Finally in the concluding section I connect Wollstonecraft's account of citizens' and rulers', including women's, political agency and participation with her critical and normative accounts of political power. Throughout, my point is that for Wollstonecraft politics, which encompasses both statecraft and the craft of forging just and productive relations in social, domestic, and intimate interpersonal contexts, connects with government (which includes rule and authority in all areas of life) and laws (including norms and informal domination). Politics is specific, and special, and not to be disavowed.

\section{Wollstonecraft's Concept of Politics}

Wollstonecraft has, as commentators insist, a theologically based idea of progress towards justice and towards the perfection of human nature and society. ${ }^{21}$ Her ethics and normative political theory are based on the possibilities and prospects of human rationality and enlightened understanding. ${ }^{22}$ But rationality and understanding go together with action. Furthermore, it is action, and uses of political power, that explain the state of society and institutions as they actually exist. Edmund Burke argued against the pretensions of philosophy and theory in the design of society and state, and for religiously based tradition to both explain and legitimate the institutions of British

Berges and Alan Coffee (Oxford: Oxford University Press, 2016); Chris Jones, "Mary Wollstonecraft's Vindications and Their Political Tradition," in Johnson, ed., Cambridge Companion to Mary Wollstonecraft.

${ }^{20}$ Berges and Coffee, eds., Social and Political Philosophy of Mary Wollstonecraft; Johnson, ed., Cambridge Companion to Mary Wollstonecraft (Cambridge: Cambridge University Press, 2002).

${ }^{21}$ Taylor, Wollstonecraft and Feminist Imagination, esp. 103-6; Taylor, "Religious Foundations"; Botting, Family Feuds, esp. 136-37.

${ }^{22}$ Taylor, Wollstonecraft and Feminist Imagination, 4. 
government and constitution. According to him the British commonwealthunlike the new revolutionary French project-had been constructed, not on the basis of "philosophic" theory, but "under the auspices and ... confirmed by the sanctions of religion and piety." 23 To this Wollstonecraft smartly answers: "Factions, Sir, have been the leaven, the private interest has produced the public good." ${ }^{24}$ This is not a normative defense of Adam Smith's view that private "selfishness" produces goods for others. It is an assertion of the role of political power in the current state. Throughout this passage, and in other parts of his Reflections, Burke repetitively uses the pronoun "we." To this, Wollstonecraft's riposte is "who?" For her, certainly, "our church and state"25 ought properly to be ours, the property of all. But their constitution has been made by the strong, who gained riches and punished the weak in order to secure them, ${ }^{26}$ and by weak princes coerced by powerful barons. ${ }^{27}$ Far from "religion and piety," this is all the upshot of faction and machiavelian politics in defense of economic power. Individuals, including Burke himself, promote their party positions, for their own individual interest, using lies, insults, and exploitation of others' shame and misery, if not force and violence. ${ }^{28}$ Religion does not explain the British or French constitutions. Political power does. And it will be political power-the capacity to act together to create institutions and distributions of authority and rights-that overturns inequality and oppression, and realizes a virtuous constitution and society.

Politics explains who does and who does not have power, authority, and material and symbolic goods, and is the key to revolution or reform. So it is extraordinarily important that it be taught in schools and discussed at dinner tables and in other social settings, and that political events, processes, and states of affairs be widely understood. In Rights of Men Wollstonecraft concedes that church pulpits are not normally the right place for political speech, ${ }^{29}$ but throughout Rights of Woman and frequently in Residence in Sweden she emphasizes how important talking and learning about politics is. In public schools, women should study political history; politics could be taught by "conversations, in the socratic form, to children in elementary schools"; and women as well as men could talk about politics in public settings. If politics were to become a subject of discussion, it would "enlarge the heart by opening the understanding," and people would exert themselves for goods beyond their families. ${ }^{30}$

${ }^{23}$ Edmund Burke, Reflections on the Revolution in France, ed. L. G. Mitchell (Harmondsworth: Penguin Books, 1993), 90.

${ }^{24}$ Wollstonecraft, Rights of Men, 34.

${ }^{25}$ Ibid.

${ }^{26}$ Ibid., 8, 11-12.

${ }^{27}$ Ibid., 9-10.

${ }^{28}$ Ibid., 26-27.

${ }^{29}$ Ibid., 16.

${ }^{30}$ Wollstonecraft, Rights of Woman, 253, 263, 275; Residence in Sweden,103. 
As has been pointed out, Wollstonecraft's relations to dissenting religious circles would have enhanced this concern with political understanding. ${ }^{31}$ Inferences were drawn from religious and theological beliefs about equality, to ideals of constitution and social relations. The effects of modes of congregation and worship on ethical values were also explicitly articulated. Further, in the wider and the dominant political culture, dissent was associated with sedition, and dissenting figures were vulnerable to political attack. $^{32}$ For Wollstonecraft, to this degree, politics is inescapable, nonoptional. The vulnerabilities of social membership, the machinations of factions, the power of barons, and machiavelian maneuvers affect the prospects and welfare of individuals and groups. People need to understand this. Politics (noun) also extends to the business of government and state generally - the formation of policy, legislation, and administration, as well as to the competition for the power to govern, and the maintenance of social hierarchy. Political (adjective) controversies and questions pertain to all these matters - not just to the working of factions. For Wollstonecraft, significantly, the question what political rights individuals have, with respect to government and state, in particular to participation in the formation of policy, in legislation, and in the competition for the power to govern, is indissolubly connected to the question of civil rights - our rights vis à vis the civic institutions of society including education and marriage, as well as property and employment. $^{33}$

In contrast to her derogatory and condemnatory references to machiavelianism, then, Wollstonecraft's understanding of politics as an explanatory factor, as an inescapable element or aspect of life in society, and as a topic

${ }^{31}$ Taylor, "Religious Foundations,” 108; Tom Furniss, “Mary Wollstonecraft's French Revolution," in Johnson, ed., Cambridge Companion to Wollstonecraft, 59-60; Karen O'Brien, Women and Enlightenment in Eighteenth-Century Britain (Cambridge: Cambridge University Press, 2009), 185-87.

${ }^{32}$ Burke's attack on Richard Price was one such; see n. 38 below. See also James E. Bradley, Religion, Revolution and English Radicalism: Nonconformity in EighteenthCentury Politics and Society (Cambridge: Cambridge University Press, 1990), 14-15.

${ }^{33}$ Rights of Woman, 67, 254-55. Lena Halldenius, "Representation in Mary Wollstonecraft's Political Philosophy," in Berges and Coffee, eds., Social and Political Philosophy of Wollstonecraft, 161, offers an interpretation of the civil-political distinction different from this. According to her reading, civil rights refer to sovereignty, whereas political rights are against oppression. I agree with Halldenius that political and civil rights are distinct as regards their functions and their place in Wollstonecraft's overall political theory. I also agree that both are theoretically linked to "natural" rights which flow from the equal status of human beings before God, and which proscribe, according to Wollstonecraft, the unnatural hierarchies of rank. Theoretically also, civil and political rights, and their lack, have implications for each other; and the doctrine of popular sovereignty is itself prescriptive of what civil and political rights citizens should have. But I have not found textual supports for her interpretation of the political/civil distinction. 
for understanding and discussion, is either neutral or commendatory. We should note the contrast between this late eighteenth-century usage and the early modern English disparagement of policy and politic, as in "Popish politic." ${ }^{34}$ Usage in the early modern period did not completely displace classical meanings, such as "good politique" as the art of government, but disparaging references are commonplace. For instance, "the politicke" means a worldly-wise person, and among these Secretarie Machiavell is notable! Locke's usage, by contrast, reflects seventeenth-century rehabilitation of the term "political." In the Second Treatise Locke uses "political" normatively and adjectivally - political power is the power to make laws, to employ the community in enforcing them, and to defend the commonwealth for the public good. Locke is concerned to distinguish this properly political power from the power of fathers over children, husbands over wives, masters over servants, and lords over slaves. None of these, for him, is political properly speaking. ${ }^{35}$

For Thomas Paine, as for Wollstonecraft, "politics" is a neutral adjective and also a noun. "I will now quit this subject, and take a concise review of the state of parties and politics in England, as Mr Burke has done in France." ${ }^{36}$ Burke's usage, by contrast, differs both from Locke's commendatory meaning, and from Wollstonecraft's and Paine's neutrality. He does use the term "politics" in the neutral descriptive sense, as a field of action: "This relation of your army to your crown will, if I am not greatly mistaken, become a serious dilemma in your politics." ${ }^{37}$ But elsewhere in Reflections he also gives "politics" an ironically inflected, pejorative meaning, recalling earlier disparagement and suspicion of "the politician": "According to this spiritual doctor of politics, if his Majesty does not owe his crown to the choice of the people, he is no lawful king"; and "It is plain that the mind of this political preacher was at the time big with some extraordinary design." ${ }^{38}$ Such association of political action in general with wizardry and

${ }^{34}$ Oxford English Dictionary, s.v. "politic." For the derogatory meaning of "policy," see N. W. Bawcutt, "'Policy,' Machiavellianism, and the Earlier Tudor Drama," English Literary Renaissance 1, no. 3 (1971): 195-209.

${ }^{35}$ John Locke, Two Treatises of Government, ed. Peter Laslett (Cambridge: Cambridge University Press, 1960), II 1, secs. 1 and 3.

${ }^{36} \mathrm{He}$ also distinguishes between "the politics of the Electorate and the politics of the Nation" (Thomas Paine, Rights of Man, in Thomas Paine: Rights of Man, Common Sense, and Other Political Writings, ed. Mark Philp [Oxford: Oxford University Press, 1995], 178).

${ }^{37}$ Burke, Reflections, 220.

${ }^{38}$ Ibid., 14, 53-54; emphasis in original. Burke is attacking Richard Price, "A Discourse on the Love of Our Country" (1789), http://www.constitution.org/price/ price_8.htm-a sermon delivered before a meeting of the London Revolution Society. The Society explicitly connected 1689 and the English bill of rights with 1789 and the Declaration of the Rights of Man and Citizen. Burke attacks Price's sermon as a mix of intriguing philosophy and political theology, and as promulgating 
"design" runs deep in European cultures. The "arts" of governing always carry an ambiguous connotation of mystery. ${ }^{39}$ The ideas that ministers operate systems of design and machination, behind the back of the sovereign, and that advisers are shadowy, are also common in political cultures, and were prominent in British politics throughout the eighteenth century. ${ }^{40}$ The association of politics with "hypocrisy" - doing harm under the guise of good, masking power-is commonplace. ${ }^{41}$ Wollstonecraft lambastes hypocrisy for its association with "priestcraft" and "superstition," but also with the machinations of cabals, and the pursuit of power over good. ${ }^{42}$ Her condemnation of duplicity, which extends from this critique of party politics to her critique of the cultures of politeness that force women, in particular, into lies, is part of the enlightenment critique of chivalric honor, gothic values, and ancien régime ways.

In Wollstonecraft's writing, shadowy advisers, machiavelian ministers, and hypocrites are certainly prominent. In Rights of Man she counters Burke's disparagement of Price's, and the revolutionists', politics by turning the tables and impugning Burke himself as the machiavelian. Burke had been led by the "odious maxims of Machiavelian policy" to consider the illness of King George III in the light of party calculations about the succession. ${ }^{43}$ In 1789 , "Machiavelian cunning ... still directed the movements of all the courts of Europe." There were "political moles" and agents working to secure the escape of the king. ${ }^{44}$ Riots in Paris were "instigated by court agents." ${ }^{\prime 5}$ This

either nonsense or "a most unfounded, dangerous, illegal, and unconstitutional position" (Reflections, 10-14).

${ }^{39}$ J. G. A. Pocock, The Machiavellian Moment: Florentine Political Thought and the Atlantic Republican Tradition (Princeton: Princeton University Press, 1975), 354.

${ }^{40}$ Ian R. Christie, Myth and Reality in Late Eighteenth-Century British Politics and Other Papers (London: Macmillan, 1970), 28-31; on the derogatory usage of "minister," see Pocock, Machiavellian Moment, 406-8, 412.

${ }^{41}$ David Runciman, Political Hypocrisy: The Mask of Power, from Hobbes to Orwell and Beyond (Princeton: Princeton University Press, 2008).

${ }^{42}$ Wollstonecraft, French Revolution, x, 12, 29, 131.

${ }^{43}$ Wollstonecraft, Rights of Man, 27. Similarly, she counters his lament for the loss of chivalry, in revolutionary times, by charging him with bad, albeit traditional, manners; and her repeated condemnation of cabals, in French Revolution (e.g., 41, 131, 250) mimics and mirrors back Burke's characterization of "the philosophes" as a cabal: Reflections, 11. See Daniel I. O'Neill, The Burke-Wollstonecraft Debate: Savagery, Civilization, and Democracy (Pennsylvania: Pennsylvania State University Press, 2007), 16; O'Neill, "Shifting the Scottish Paradigm: The Discourse of Morals and Manners in Mary Wollstonecraft's French Revolution," History of Political Thought 23, no. 1 (2002): 105-6; David Bromwich, "Wollstonecraft as a Critic of Burke," Political Theory 23, no. 4 (1995): 617-34.

${ }^{44}$ Wollstonecraft, French Revolution, 415.

${ }^{45}$ Ibid., 63, 93. 
machiavelianism was contagious - suspicion meant that the people themselves (on the march to Versailles, for instance) were engaged in "intrigue" and rumor mongering. ${ }^{46}$ She also emphasizes the perversities of factional reason: for instance, in 1788 the parliament opposed a popular edict in favor of protestants simply because "it came from another quarter, although ten years previously they had been in favour of such a measure." 47 And she emphasizes what we might call "constructive ambiguity" and strategic misunderstandings - for instance, the king interpreted a request for his sovereign sanction for a measure as a request for his opinion and analysis of it. ${ }^{48}$ These styles are presented as running deep into the governance of states, into the work of those who govern: "The statesman, it is true, might with more propriety quit the Faro Bank, or card-table, to guide the helm, for he has still but to shuffle and trick." ${ }^{49}$ Gambling is good training for the tricky game of politics as that is practiced by corrupt and violent government.

All of these are familiar negative descriptions of what is ordinarily thought of as political reason and action. But notwithstanding machiavelianism, factionalism, and domination and exploitation by the rich and powerful, politics and policy are by no means inherently negative. Politics is just all the business, events, actions, and processes that surround the power or authority to govern-competing for it, winning or losing it, challenging and opposing it, deploying it, whether virtuously or corruptly, and not necessarily intentionally. People can be caught up in politics unawares. Policy can be machiavellian, or despotic. Alternatively it can be that of just and enlightened ministers. It can be unsound; or it can be the best possible. ${ }^{50}$ Learning about and knowledge of politics and policy are, for Wollstonecraft, unambiguously good things. In Wollstonecraft's work, we find a coexistence between machiavelianism, corruption, and domination by the rich and powerful, to be repudiated, and a politics to be developed, based on scientific and rational political economy and government, on citizen participation, and on the just correlation between duties and rights.

Underpinning this politics to come is popular sovereignty, although she does not use that term explicitly. In France, events from 1787 "provoked a discussion which led to the most important question of all-namely, in whose hands ought the sovereignty to rest? - who ought to levy the impost and make laws?"51 In Rights of Men she invokes William Blackstone in support of the idea that the succession of the king of England depends on the choice of the people. $^{52}$ If Blackstone is correct, popular sovereignty is a

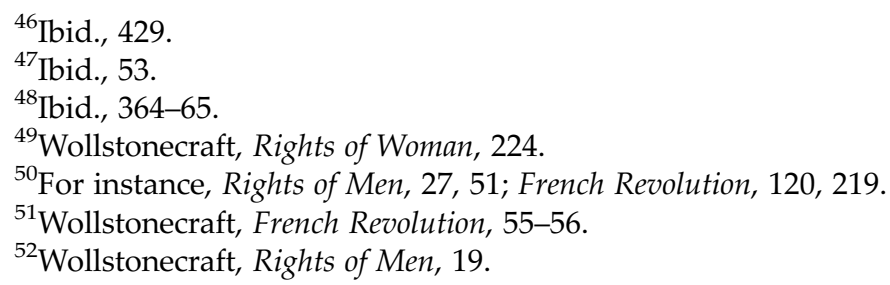


legal principle; for Wollstonecraft it is, in any case, a moral one. More importantly, it is a political matter of fact, independent of positive law. Where, actually, does the power lie? In the end, as the events in France 1789 and in England 1688-89 $9^{53}$ show, the people can overturn the established authority, can choose their form of government, and in appropriate conditions they will. As Wollstonecraft puts it, emphasizing the irresistibility of the people's power: "unable to endure the increasing weight of oppression, they rose like a vast elephant, terrible in his anger, treading down with blind fury friends as well as foes." ${ }^{\prime 54}$ But there is more to the people's power than sheer might and anger: "People thinking for themselves have more energy in their voice, than any government, which it is possible for human wisdom to invent; and every government not aware of this sacred truth will, at some period, be suddenly overturned." 55 The frankness of the people is the opposite of the hypocrisy of the cabal. ${ }^{56}$

The "sovereignty" of individuals over other individuals, on the other hand, is bogus. She mocks the idea that an individual can rightfully lord it over others, whether as incumbent of the office of monarch or as head of a family. Of course, as things stand, in a world in which women have no civil or political rights, men have absolute, violent power over their wives and families. They might as well be given whips on their wedding day, to "reign, wielding this sceptre, sole master of his house, because he is the only being in it who has reason; the divine, indefeasible, earthly sovereignty breathed into man by the Master of the universe." ${ }^{57}$ She consistently ironizes and deflates the pretensions to sovereignty of patriarchs and others-by implication ironizing the sovereignty of monarchs also. People can, as a matter of historical fact, and because of the workings of political power, be enslaved. They can be dominated by rulers who assert divine right, or by a class or group, like the aristocracy, who consider themselves to have natural superiority or governing authority. That they can dominate does not mean that they should. It is only political power that will relocate sovereignty to its proper place. Wollstonecraft is not interested in-other than to ironize or mock - metaphysical theories such as divine right. She is impatient of conceits like the social contract, just as she is impatient of Burke's reaching back in historical time for the origin of the rights and privileges that the constitution distributes. ${ }^{58}$

\footnotetext{
${ }^{53}$ See n. 40 above.

${ }^{54}$ Wollstonecraft, French Revolution, 32; Halldenius, Wollstonecraft and Feminist Republicanism, 102.

${ }^{55}$ Wollstonecraft, French Revolution, 492.

${ }^{56}$ Ibid., 131.

${ }^{57}$ Wollstonecraft, Rights of Woman, 283.

${ }^{58}$ Wollstonecraft, Rights of Men, 40; French Revolution, 7; Halldenius, “Representation," 175.
} 
Wollstonecraft often uses the conventional terms "the people" and "the nation." In French Revolution people and nation are subjects of action, feelings, and thoughts. In Rights of Men, as we have seen, she argues that the government is the choice of the people. Throughout, her usage is equivocal at best about the corporate or unified, as opposed to the aggregate, sense of "the people." Following Rousseau, the people constructed as sovereign should properly be referred to as an entity-grammatically, the people decides, elects, demands, and so on. In the course of the revolution, the people of France did speak-"The nation, with one voice, demanded justice." However, throughout her work, Wollstonecraft emphasizes division and disunity among "the people." There are the enforced and artificial distinctions of rank and status. And there are the material inequalities and deprivations that track those status distinctions. Some people-because they are poor, or are mechanics, or women-are disadvantaged and harmed by other people and by the laws and norms. Those who have, because of want of education, nutrition, housing, or other goods, been rendered weak and "unqualified to judge with precision of their civil and political rights" ${ }^{60}$ are the ones who are called upon to exercise those rights. This means that a distinction has to be drawn between the sovereign will of the people (singular) as it ought to be, and the actual voices of the actual people (plural).

At worst, the habits and conduct of the repressive state, and the casual violence of the oppressing and exploiting classes, can generate the violence of frustrated demanders of change. Meanwhile, the allocation of rights and privileges that depend on the subjection and subordination of "inferior" classes - as aristocracy over middle- and working-class people, as men over women-means that the privileged are incentivized to use permissible means, including brutality, to keep subordinates down. ${ }^{61}$ In particular, absence of cultures of discussion and reasonable disagreement predisposes people-both powerful and powerless - to uses of violence. For many, brutality is a way of life. ${ }^{62}$ For Wollstonecraft, violence is the threat of the descriptive fact of popular sovereignty (the damage the elephant can wreak), and it is a threat to any normative theory of popular sovereignty. At the same time the fact of violence explains how subordination has been achieved in the past. In Rights of Men she challenged Burke on his constructions of popular protest as the work of a violent mob. He sees monsters where she sees women who make a living selling vegetables or fish; he sees outrageous violence where she sees people demanding what is right, and transferring authority from the court to the assembly. ${ }^{63}$ In French Revolution she herself uses terms such

\footnotetext{
${ }^{59}$ Wollstonecraft, French Revolution, 57.

${ }^{60}$ Ibid., 7; also 511 on how "cast-like society" destroys the character of superiors and debases the inferior to machines.

${ }^{61}$ Wollstonecraft, Rights of Men, 59-60; Rights of Woman, 104.

${ }^{62}$ Wollstonecraft, French Revolution, 256, 261, 521.

${ }^{63}$ Wollstonecraft, Rights of Man, 29.
} 
as "mob," lamenting popular violence and the loss of reason in political transformation. ${ }^{64}$ Throughout, though, she is consistently concerned to explain violence-whether a mother's violence to her children, a husband to wife, a participant in protest to property or persons - by way of social and cultural conditions and political constitution. Who uses violence, to whom, can be explained by the distribution of rights and privileges, their attendant capacities and frustrations, and their efforts to gain or to maintain position. That is how hierarchical polities and societies work.

Wollstonecraft's core conception of politics, then, is centred on the power people do have, and can exercise, both to decide how government should be organized and to set up institutions and procedures of government, including public policy and law. This power is competed over-the point of her work is to count as a series of moves in the fight to wrest governing power from those who have held it for centuries, to uncover the popular sovereignty that actually and rightfully maintains governing institutions, to ensure that the duties and rights relevant to government and the state are distributed justly. The petty competitions within governing classes and regimes in the past have favored the hypocrites, the machiavelians, the ruthless. Wollstonecraft's commitment is that in future political competition be conducted openly and honestly.

\section{Wollstonecraft's Normative Theory of Politics}

For Wollstonecraft, the extension of rationality to public and to social life, the potential for all to share in rational judgment, and perfection in the science of government are all reflections of God's purpose. The economy-flows and distribution of material goods - can be rationally and justly managed by governments. Values and truth can be simply expressed and manifest in our ways of life; duties and rights can be justly distributed, and simply and openly discharged and exercised. This theme of simplicity, which, as Sapiro observes, is one of Wollstonecraft's favorite adjectives, whether in connection with truth, argument, moral principles, or dress, ${ }^{65}$ is central to her normative theory of politics. It is connected for her to the qualities of a healthy body, which presupposes a just distribution of material goods. As commentators insist, the just distribution of goods and rights secures relations of independence of each from any. ${ }^{66}$ Simple scientific procedures in government will be conducive to the effective exercise of popular sovereignty and to real political representation. This society and polity of independence and simplicity, in turn, depend on the correct relationship between duties and rights.

\footnotetext{
${ }^{64}$ Wollstonecraft, French Revolution, 93, 194.

${ }^{65}$ Sapiro, Vindication of Political Virtue, 215-16.

${ }^{66}$ Coffee, "Wollstonecraft, Freedom, and Social Domination"; "Freedom as Independence"; Halldenius, Wollstonecraft and Feminist Republicanism.
} 
The coming theme of simplicity puts Burke firmly into the reactionary past. In Rights of Men a good deal of Wollstonecraft's attack on Burke is on the terrain of his aesthetics and his style. ${ }^{67}$ His commitment to tradition-a tradition that reaches back into the ages of barbarism - is attributed to his "gothic" sensibility which is contrasted with the "civility of liberal man." Gothic, and romantic, values "destroy all simplicity, which in works of taste is but a synonymous word for truth." ${ }^{68}$ This aesthetic value of simplicity, and the way plainness, in food, way of life, and manners, contrasts with the incapacities of those who are corrupted, is repeated through the book. ${ }^{69}$

In Rights of Woman the arguments for and from simplicity are developed. Quite frequently, Wollstonecraft uses the word in the familiar rhetorical move of disavowing difficulty and asserting the obviousness of truth: "My main argument is built on this simple principle..." ${ }^{70}$ The opening sentence is an avowal of her project of uncovering: "It appears necessary to go back to first principles in search of the most simple truths, and to dispute with some prevailing prejudices every inch of ground." ${ }^{71}$ Her conclusions "consist in a few simple principles, and clearing away the rubbish that obscured them." ${ }^{\prime 2}$ The reconstitution of virtues, relevant to all persons, applicable both to public and to private, is built around simplicity in its logical, its aesthetic, and its ethical meanings. The honesty of friendship, and simple affection, contrasts with the intrigue of the marriage market and libertine sexualities. ${ }^{73}$ The decently and honestly clothed natural body contrasts with the artificiality and deception of fashion and ornament. We find this thought also in her earlier Thoughts on Education-dress ought to adorn the person, not to rival it. ${ }^{74}$ The simply clothed body will be healthy, and will allow the development of a healthy mind. ${ }^{75}$

In French Revolution simplicity is a political and constitutional principle as much as an ethical and aesthetic one. Simplicity features in Wollstonecraft's account of civility and civilization, her account of social, political, and moral equality, and her account of political constitution. As a political

${ }^{67}{ }^{\prime}$ Neill, Burke-Wollstonecraft Debate; Bromwich, “Wollstonecraft as Critic of Burke"; Bahar, Eve to Please Me.

${ }^{68}$ Wollstonecraft, Rights of Men, 28; also 8, 16, 41.

${ }^{69}$ Ibid., e.g. 42, 58.

${ }^{70}$ Wollstonecraft, Rights of Woman, Dedication, 66.

${ }^{71}$ Ibid., 76.

${ }^{72}$ Ibid., 282.

${ }^{73}$ Ibid., 250.

${ }^{74}$ Mary Wollstonecraft, Thoughts on the Education of Daughters, ed. Gina Luria (New York: Garland, 1974), 16.

${ }^{75}$ Wollstonecraft, Rights of Woman, 14, 129, 131, 137; Residence in Sweden, 114, 186-87; John McCrystal, "Revolting Women: The Use of Revolutionary Discourse in Mary Astell and Mary Wollstonecraft Compared," History of Political Thought 14, no. 2 (1993): 195. 
principle, the idea of a single legislative chamber was attractive to many, and can be identified as an element of eighteenth-century republican thought. It had been a point of contention in the US constitutional debates, was contested in the development of the French postrevolutionary governing institutions (the first constitution of 1791 established a unicameral assembly), and is adverted to by many commentators. ${ }^{76}$

The themes of simplicity, rationality, and health connect with Wollstonecraft's theory of duties and rights and with her political economy. Her work is commonly read as a key contribution to the critical and normative arguments regarding the extension of civil and political rights to women. Critics vary, however, in their readings of Wollstonecraft's rights theory. Some question the extent to which the second Vindication is centrally about rights at all, as opposed to a more complex set of politically, ethically, and aesthetically relevant concepts. ${ }^{77}$ While some interpret her arguments in the terms of feminist human rights theory, ${ }^{78}$ others take a more problematic view, emphasizing the paradoxical and strained relationship between woman and human, or between woman and rights. ${ }^{79}$ There is disagreement about the sources and references for her conception of rights, in particular the relevance of Lockean natural rights theory for her normative theory of human authorship of civil rights. ${ }^{80}$ Here I want to argue for an interpretation which emphasizes the closeness of rights with duties for Wollstonecraft, and which has bearing on her concept and normative theory of political power.

The emphasis here differs somewhat from that on the nullity of duties absent rights, as highlighted by Halldenius. ${ }^{81}$ Undoubtedly, where there is

\footnotetext{
${ }^{76}$ Catharine Macaulay, "Sketch of a Democratical Form of Government," in Loose Remarks on Certain Positions to Be Found in Mr Hobbes's Philosophical Rudiments of Government and Society; with a Short Sketch of a Democratical Form of Government, in a Letter to Signor Paoli (London, 1767), 30-32; On Burke's Reflections on the French Revolution, ed. Jonathan Wordsworth (Washington, DC: Woodstock Books, 1997), 48, 50, 80-81; James Madison, Alexander Hamilton, and John Jay, The Federalist Papers, ed. Isaac Kramnick (Harmondsworth: Penguin Books, 1987), 366-74; Paine, Rights of Man, 252-54.

${ }^{77}$ Sapiro, Vindication of Political Virtue, xxv; Abbey, "Are Women Human?," 229-30.

${ }^{78}$ Abbey "Are Women Human?"; Botting, Wollstonecraft, Mill, and Women's Human Rights.

${ }^{79}$ Natalie Fisher Taylor, The Rights of Woman as Chimera: The Political Philosophy of Mary Wollstonecraft (New York: Routledge, 2007); cf. Wollstonecraft, Rights of Woman, 106.

${ }^{80}$ Susan James, "Mary Wollstonecraft's Conception of Rights," in Berges and Coffee, eds., Social and Political Philosophy of Wollstonecraft; Lena Halldenius, "The Primacy of Right: On the Triad of Liberty, Equality, and Virtue in Wollstonecraft's Political Thought," British Journal for the History of Philosophy 15, no. 1 (2007): 75-99; Wollstonecraft and Feminist Republicanism, 34-39; Botting, Wollstonecraft, Mill, and Women's Human Rights, 81-83; McCrystal, "Revolting Women," 202-3.

${ }^{81}$ Halldenius, "Primacy of Right," 93.
} 
a lack of civil right, Wollstonecraft insists on a corresponding absence of civil duty or obligation. In French Revolution, she remarks of some laws prior to 1789 that "the duty lies in the breach, not in the observance"; ${ }^{82}$ and the same is true of unjust laws that exact severe penalties including death for thefts like poaching. ${ }^{83}$ Disobedience to unjust laws is permitted, according to Wollstonecraft, and in certain circumstances might even be enjoined. However, we must take care with inferences from the absence of right to the absence of duty as such. For Wollstonecraft, we have natural rights which correlate with our natural duties to others.

The birthright of man, to give you Sir, a short definition of this disputed right, is such a degree of liberty, civil and religious, as is compatible with the liberty of every other individual with whom he is united in a social compact, and the continued existence of that compact. ${ }^{84}$

Our natural duties (in particular the nonviolation of and respect for the natural freedom of others which is their natural right) are not negatable. Of course, civil and political rights can fail to make good on natural rights. In that case, the legitimacy of civil or political duties is in question. To insist that women or working people have a civil duty to uphold government authority, for instance, is only an oppressive use of unequal political power. But this does not rule out the imperative of natural duty.

We can see why commentators might interpret Wollstonecraft as arguing that the violation of natural rights cancels out natural duty. She explains women's neglect of duty by way of their lack of freedom:

The wife, in the present state of things, who is faithful to her husband, and neither suckles nor educates her children, scarcely deserves the name of a wife, and has no right to that of a citizen. But take away natural rights, and there is of course an end of duties. ${ }^{85}$

But we should not, in my interpretation, read that final sentence as saying that women should not be held to their natural, as opposed to their civil, duties. Her emphasis, rather, is on the nonnegotiability and nonoptionality of natural duties. In particular, terrible parenting is a violation of children's natural right to freedom. Parents and other adults have a natural duty to respect, and to foster the conditions for the exercise of, this natural right. Of course, social, cultural, and political conditions can corrupt people in their natural duty and undermine the conditions for the exercise of natural right. These are the processes that Rights of Woman is dedicated to analyzing, and

\footnotetext{
${ }^{82}$ Wollstonecraft, French Revolution, 97.

${ }^{83}$ Wollstonecraft, Rights of Men, 7; Lena Halldenius, "Mary Wollstonecraft's Feminist Critique of Property: On Becoming a Thief from Principle," Hypatia 29, no. 4 (2014): 946-47.

${ }^{84}$ Wollstonecraft, Rights of Men, 7.

${ }^{85}$ Wollstonecraft, Rights of Woman, 227.
} 
which Wollstonecraft's prescriptions of new civil, legally entrenched rights are designed to transform. Natural duties, according to Wollstonecraft's political theory, are properly socially enforceable. ${ }^{86}$

This analysis of natural duties is implicated also in what Wollstonecraft says about class justice. Poor households, including poor children, lack necessities, and government and society are unresponsive to their needs.

The whole system of representation is now ... only a convenient handle
for despotism. [Women] need not complain, for they are as well repre-
sented as a numerous class of hard working mechanics, who pay for
the support of royalty, when they can scarcely stop their children's
mouths with bread. How are they represented?

The answer, of course, is not at all. The natural rights of the poor are compromised in the way that the natural rights of women are. Yet, poor people have duties, to care for their children and, Wollstonecraft here implies, to live independent lives. The discharge of duty justifies the recognition and upholding of the natural right to freedom, just as natural rights entail the natural duties of others. It also justifies the extension of civil and political rights-here, rights of representation in particular-to workers and the poor.

Respect, Wollstonecraft insists, is owed only to those who properly discharge their duties. ${ }^{88}$ The discharge of duties by all, correlational with the enjoyment of rights by all, equalizes, reflecting the equality of all before God. It also requires equalization with respect to the resources necessary for independence, and hence for the exercise of the right to freedom. No one should be treated with contempt or condescended to because of their work or level of income; nobody is to be emulated or worshiped because they are rich or wear splendid clothes. For Wollstonecraft this demand for relational equality involves leveling down. In particular, those who are used to parading their superiority and maintaining the differentials of rank by working actively to denigrate the "inferior," to disavow those who cross rank boundaries, to prevent such boundary crossings, will have to give all that up. Such relational leveling will involve a degree of material redistribution: the poor need more in the way of necessaries, and the rich must have far less in the way of luxury. ${ }^{89}$ Such leveling, and equalization, is a government

${ }^{86}$ Laura Brace, "Not Empire, but Equality: Mary Wollstonecraft, the Marriage State, and the Sexual Contract," Journal of Political Philosophy 8, no. 4 (2000): 434-36. In Coffee's interpretation ("Freedom as Independence," 917), we must be under social obligations to allow natural duties to be discharged.

${ }^{87}$ Wollstonecraft, Rights of Woman, 228.

${ }^{88}$ Ibid., 222.

${ }^{89} \mathrm{Ibid} ., 228$. An anonymous reader of an earlier version of this paper interpreted my analysis here as implying that Wollstonecraft is a kind of Rawlsian avant la lettre. On the contrary, Wollstonecraft's emphasis on the effort that has to be put into the "having" and the keeping of the rights and privileges of rank and inequality puts 
duty. ${ }^{90}$ The question of how governments can be constrained to discharge this duty is, of course, at the heart of her political theory. In the Vindications in particular, in her hints about a further book on political representation, ${ }^{91}$ her focus is on the selection of assembly representatives, of governmental officers, and the formation and implementation of public policy. There is a vicious circle of corruption and venality in the buying of votes, with the concomitant unseriousness of the act, and the low expectations that voters then have of those they elect. Machiavelian norms of political conduct and the venality of the vote-buying system effectively rule out disinterested, let alone wise, conduct from individuals elected to office. ${ }^{92}$

As Bahar points out, Wollstonecraft's arguments about political representation and equality are intertwined with her objections to how poverty and wealth are represented, in philosophy and by those who speak about and depict them..$^{93}$ Elements of the public culture are revolted by work, and see poverty as ugly. There are two strands to Wollstonecraft's response. First, as in her dispute with Burke on political conduct, she turns the tables. The working poor, who "cannot stop their children's mouths with bread," are treated to the appalling spectacle of luxury and splendor by the idle rich on parade in their carriages. It is this that is repulsive, according to Wollstonecraft's aesthetics. ${ }^{94}$ Burke's wish to veil the body of the monarch in a sacred halo, to banish the poor of Paris from their public places, and to quiet their voices, in order to remove the ugly and the monstrous from the scene, is not only an aesthetic error (although Wollstonecraft does grant that poverty can be repulsive), but more importantly a political one. The poor are called upon to gape, and ape, and admire what warrants no respect. Second, she reveals the work and effort that underpin the production of any thing - whether the luxurious superficiality of aristocratic splendor or the valuable necessities of daily life. Artificial distinctions of rank take

her into a different camp from the twentieth-century liberal thinkers who emphasized distribution of rights, wealth, and so on but tended not to dwell on the efforts-including individual actions and the maintenance of structures - that go into the keeping of them. Wollstonecraft offers a social and political theory of this effort, and her analysis is the more illuminating of the necessary conditions the equalization that is demanded by the natural equality of right and duty.

${ }^{90}$ Halldenius, "Primacy of Right," 93-96; Wollstonecraft, French Revolution, 7.

${ }^{91}$ Wollstonecraft, Rights of Woman, 228. Critics read Wollstonecraft's unfinished The Wrongs of Woman, or Maria (in Mary Wollstonecraft: Mary, and the Wrongs of Woman, ed. Gary Kelly [Oxford: Oxford University Press, 1976], 71-204) as the text in which she begins to work out her political theory of rights and law. See Bahar, An Eve to Please Me, 172-73; Halldenius, "Wollstonecraft's Feminist Critique of Property," 946-47.

${ }^{92}$ Wollstonecraft, Rights of Man, 36.

${ }^{93}$ Bahar, An Eve to Please Me, 143-45.

${ }^{94}$ Wollstonecraft, Rights of Woman, 228. 
considerable effort-laws and violence - to maintain. Any object has been preceded by process. ${ }^{95}$ Critics emphasize that Wollstonecraft is inclined to paint romantically beautiful pictures of work - the cottage, the agricultural family coming home to simple comforts. ${ }^{96}$ But, more importantly, the depiction and the understanding of labor, and of want-of the material effort that underlies appearances of beauty and ugliness, of the materiality of inequality, - is itself necessary if philosophy is to be valid.

This is the political theoretical context for Wollstonecraft's specific references to political economic measures taken by the French revolutionary government. Her insistence, throughout her works, on political economy as the explanans of the status quo and projected outcomes of reform, and a significant topic for citizen understanding, is striking. In the final pages of French Revolution, Wollstonecraft endorses physiocratic economic principles, which propose taxation on surplus produce, net of the needs of the producer, for politically necessary ends only, while talents and industry should be free. ${ }^{97}$ It is notable that Wollstonecraft highlights - where other commentators and historians of the revolution do not-the Assembly measure of free circulation of grain, sanctioned by the king on the day of the march on Versailles. ${ }^{98}$ Packham points out that Wollstonecraft's characterization of this measure in terms reminiscent of grain trade liberalization is controversial. This approach to scientific political economy and free trade, characteristic of the Scottish enlightenment, is also at odds with earlier chapters and with Rights of Woman, where political economy is more part and parcel of the ideal of wise and just government. In Residence in Sweden, Wollstonecraft emphasizes her concern that markets for goods should be such as to permit and incentivize production, and she contrasts grubby commerce to healthy exchange of goods for needs and to the social conditions in which progressive ideas can circulate and healthy habits form. ${ }^{99}$ Packham also notes that, despite its prominence in the chapter heading, in the text Wollstonecraft's account of this event is overshadowed-as it was, indeed, on the day-by the march on Versailles and the exercise of coercive, popular power. For my purposes, the crucial point is that Wollstonecraft here, as throughout her work, relates questions of property rights and distribution, production and trade, to her central questions of political rights, moral character and duties, and revolution or reform in state, society, and manners. For her, politics and government, political economy, and political virtue are bound together.

\footnotetext{
${ }^{95}$ Catherine Packham, "Genre and the Mediation of Political Economy" (unpublished manuscript), 16; Bahar, An Eve to Please Me, 23, 161.

${ }^{96}$ Packham, "Domesticity, Objects and Idleness," 554; “Wollstonecraft's Cottage Economics," 453-54, 464.

${ }^{97}$ Wollstonecraft, French Revolution, 499; Packham, “Common Grievance," 705-6.

${ }^{98}$ October 5, 1789: Wollstonecraft, French Revolution, 420 (this is within the chapter heading of bk. 5, chap. 2),436. See Packham, "Common Grievance," 708-9.

${ }^{99}$ Wollstonecraft, Residence in Sweden, 103-5, 106-7, 115-16.
} 


\section{Political Power and Political Theory}

For Wollstonecraft political power-how it is distributed and deployedexplains the injustices of her society. For her, this injustice is a reflection of the corruption of politics and can be righted by political power, of the right sort, used properly, for just ends. Political power of the right sort is firmly grounded in popular sovereignty and in the ethical-political project of the enforcement of natural duties, for the realization of all individuals' natural right to freedom. This necessitates reconstituted and redistributed civil and political rights, and government of economy, justice, and society accordingly. The enforcement of, and indeed the permitting conditions for, the discharge of natural duty and the exercise of natural right themselves necessitate transformation in individuals' social relations with one another. Popular sovereignty means that all individuals are rightly implicated in such transformation and government.

Prescriptively, Wollstonecraft's account of the natural right to freedom justifies a specific distribution of material goods which in turn has to be instituted and guaranteed by right, in order that independent individuals can truly act freely. As Coffee argues, this free action-citizenship as public presence and action-presupposes several conditions. ${ }^{100}$ First, the economic distributions we have discussed. Second, the equal protection of the rule of law. Third, open, nonviolent public spaces for action. Women must be able to speak, to be heard, to be listened to, in public, without fear of legal or political exclusion, and without the threat of violence or intimidation. In The Wrongs of Woman an act of the drama focuses on Maria's right to plead her own cause in a court of law, to be recognized by the state as a citizen and a full legal person. She speaks-not vocally, but in writing-but she is not heard by the judge. ${ }^{101}$

In French Revolution Wollstonecraft achieves voice in the persona of political judge, as well as dramatic narrator. Her story focuses on the moral aspects of the situations, the characters, and their actions. What happened, how, why, and what happened consequently; who the key actors were; what were the sources of the political power they deployed, or lacked; what they thought they were doing; and what the consequences were of what they said and did. Characters frequently are named individuals: Calonne, an "artful though weak Machiavelian politician,"102 and Louis XV, "a slave of his mistresses, his kingdom ransacked to satiate the cormorants, corrupting morals, breaking the spirit of the nation." ${ }^{103}$ Other characters in this moral

\footnotetext{
${ }^{100}$ Coffee, "Freedom as Independence," 909.

${ }^{101}$ Wollstonecraft, Wrongs of Woman; Coffee, "Wollstonecraft, Freedom and Social Domination," 125-26; cf. also Bahar, An Eve to Please Me, 172.

${ }^{102}$ Wollstonecraft, French Revolution, 42.

${ }^{103}$ Ibid., 32.
} 
drama are collective actors: the nobles, the clergy, the assembly. The reactionary courts of Europe are directed by "Machiavelian cunning." ${ }^{104}$ The characters are not confined to the "elite" and prominent, however. Importantly, the nation as a whole, the people, are or is an actor. ${ }^{105}$ Wollstonecraft shows us characters who lack foresight or proper responsibility. Her analysis emphasizes how political actions have unexpected or uncontrollable consequences. However, with more thoughtful deliberation, and more judicious action, those consequences were not unforeseeable. For instance, courtiers should have seen that "the moment was arrived, when subterfuge and treachery could no longer escape detection and punishment." ${ }^{106}$

In addition to these judgments about what political actors should have known, understood, or foreseen, Wollstonecraft frequently emphasizes the difference between how things seemed and how they really were. For instance, the Assembly got the support of the cities and some clergy by abolishing monopolies that were disadvantageous to city authorities and by increasing some clergy salaries. What looks like virtue and patriotism was really "pay and plunder." ${ }^{107}$ Some judgments are delivered more indirectly, via ethically and politically infused language, such as that Necker was "intoxicated by popularity" when he issued the general amnesty in August 1789, or that Mirabeau's attempts to both keep a hold on the court and lead the people are instances of "the pitiful shifts of men who are not guided by the compass of moral principles." 108

The story, as it stood at the time of writing in 1794, had a tragic structurepolitical power had been misused and squandered. The culprits were the machiavelians, the hypocrites, and also those who thought of politics in terms of deals and profits, commerce and bargaining. This kind of motivation and action corrupts human relations and social institutions and crowds out the production and circulation that meet human needs. At worst, as we have seen, the model for politics becomes gaming and gambling, oblivious to human life. The conundrum of how political power can be made productive, how its risks can be obviated, is one that the texts return to. Her observations of politics, government, culture, and society, in Britain, France, and Scandinavia, impress Wollstonecraft with the power of material cultures. Habits and norms governing household economies, dress and health, diet and childcare are as powerful as institutions such as the male homosociality of the gaming tables and female subjugation and competition in the marriage market in entrenching ideas about what everybody does and sanctioning

\author{
${ }^{104}$ Ibid., 414. \\ ${ }^{105}$ Ibid., 65-66, 247, 464. \\ ${ }^{106}$ Ibid., 215. \\ ${ }^{107}$ Ibid., 292-93. \\ ${ }^{108}$ Ibid., 272, 472.
}


those who deviate from norms. How can these be changed? In Scandinavia, she thinks of the ideal of benevolent legislation and good government:

Reflecting on these principles made me revert to the wisdom of those legislators who established institutions for the good of the body under the pretext of serving heaven for the salvation of the soul. These might with strict propriety be termed pious frauds. ${ }^{109}$

So, obviously, this is ironic. Wollstonecraft cannot really entertain noble lies, even were real politicians ideal statesmen. Even the norms of classical republican politics - for instance, the process of conciliating rival projects and interests so as to create space and conditions for a decision-are negative when they are not constrained firmly by justice, or where the conciliator's motives are suspect. Mirabeau's attempts to conciliate the French court and king were disastrous. ${ }^{110}$ Mirabeau was using political power-the resources and capacities generated by his position, his knowledge, his ability to persuade others, and to act in concert with them. He was not using it in the right way, to build the right relationships.

Nevertheless, this is the power that is needed to turn economy, and culture, in the right direction, and to establish governments that equalize and secure justice. In particular, women should be educated about politics, and should participate in the exertion of sovereignty to ensure justice and good government. Politics is a fit occupation for women, from which they might make a living, for which they should be able to train. ${ }^{111}$ Political judgment, like legal reasoning and pleading, are functions that women can, and should have a right to, discharge. Wollstonecraft urges, and effects with her interventions, more than one shift in the concept of politics. First, as is well known, she extends it into relationships that had formerly been outside its ambit. Second, she opens it up to a wide participation, of a new kind, by individuals who, by definition, do not have effectively tyrannical power in their own allegedly sovereign domains. She fully endorses the negative evaluation of machiavelian arts, while promoting the possibility of virtuous popular sovereignty. She anticipates and aims at a context in which civil and political rights guarantee that speech and action like hers is considered legitimate.

Wollstonecraft's theory is political in several senses. First, it focuses for much of the time on what is conventionally thought of as the field of politics - the public (and the machiavelian) competition between parties or factions for the authority to govern, the formation and implementation of public policy, the correspondence between natural duties and rights, and the civil and legal rights that are presided over by government. Second, it is prescriptive in the sense consistent with the standard view that political

\footnotetext{
${ }^{109}$ Wollstonecraft, Residence in Sweden, 116; also Rights of Woman, 264; French Revolution, 521.

${ }^{110}$ Wollstonecraft, French Revolution, 472ff.

${ }^{111}$ Wollstonecraft, Rights of Woman, 228-29.
} 
theory is just the application of moral principles to matters of public and governmental concern. But, third, Wollstonecraft also tries to bring clearly into view how the power to rule and dominate is exercised, whether for good or for ill. At this diagnostic and critical level her insights about cultures both social and domestic, and about the embodiment of forms of power, are very significant for later feminist and critical theories that government, representation, and formal rights and liberties are in the first place the spectacular form that dominating power takes, and second not the point at which change has to be made if real transformation of welfare, relationships, and justice in rules and authority is to be realized. Fourth, Wollstonecraft's theory is programmatic as well as prescriptive. She premises her work on the possibility, in her time, of strategically formulated arguments about duties and rights, and sovereignty, being intelligible, informative, and persuasive.

Fifth, though, Wollstonecraft's theoretical texts, as well as offering critiques, analyses, and justifications, themselves constitute a political intervention. For Mary Wollstonecraft, writing is not simply "about" politics. As I have argued, she believed knowing about politics to be critically important, for all, and especially for all who are oppressed. But in thinking, arguing, writing, and publishing, she was engaging in politics-she was doing it. Among the things she was doing was effecting a shift in the very meaning of politics itself, while endorsing the particular nature of political power. This is among the most important of her feminist legacies. 